\title{
Hommage à Dali
}

$\mathrm{J}$ 'ai entendu se peindre une peinture.

Elle m'a vu 1 'écouter:

elle a l'air de pendules flasques, de têtes bulbeuses. Un port resplendit--rêve métaphorique réalisé!

Une guêpe entre en volant dans un oeil;

un tigre en sort.

Colombe débarque et débarque,

des machines pensantes battent et battent.

Le spectre regarde tout.

Dali I'enfant s'échappe:

se heurte contre le Temps,

tombe doucement.

I1 voit les cheveux de poètes qui flottent, voit le chien de Chester, qui le regarde fixement.

I1 attend I'enfant Jésus-Christ

mais tous les plaisirs donnent libre cours aux passions de 1 'esprit.

Il crie,

il peint la réponse.

Il casse un oeuf, verse le jaune qui est son âme.

Il se dévore en cauchemar

et je 1 'entends.

Il se moque du Temps, des pendules flasques.

(Un oeil, une assiette et en voilà une autre.)

Enfin Gala 1'épouse,

la seconde âme où l'ordre se cache.

Mark W. McRae et Christopher R. McRae

Vanderbizt University 


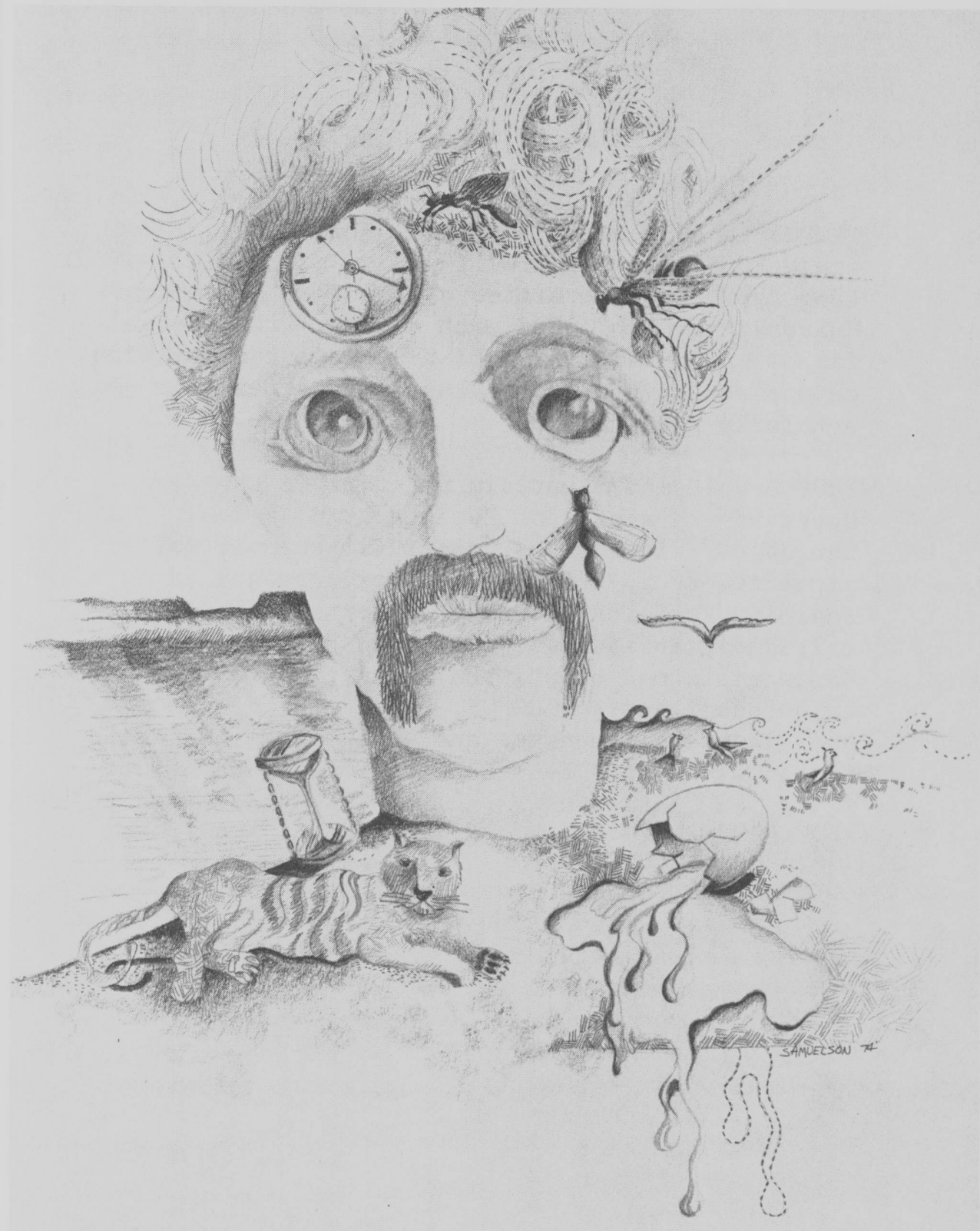

